\title{
The Bird Community in a Threatened Coastal Lagoon in Southeastern Brazil
}

\author{
Davi Castro Tavares ${ }^{1 *}$, Salvatore Siciliano ${ }^{2}$ \\ ${ }^{1}$ Laboratório de Ciências Ambientais, Universidade Estadual do Norte Fluminense (UENF), \\ Campos dos Goytacazes, Brazil \\ ${ }^{2}$ Escola Nacional de Saúde Pública Sergio Arouca-FIOCRUZ, Rio de Janeiro, Brazil \\ Email: "wetlandbirdsbrazil@gmail.com
}

Received 8 January 2014; revised 8 February 2014; accepted 15 February 2014

Copyright (C) 2014 by authors and Scientific Research Publishing Inc.

This work is licensed under the Creative Commons Attribution International License (CC BY). http://creativecommons.org/licenses/by/4.0/

(c) (i) Open Access

\begin{abstract}
We provide a list of bird species for Ribeira lagoon, a protected area in Rio de Janeiro, southeastern Brazil. Data were obtained in monthly surveys in points along a continuous transect, between August 2008 and July 2009, and 21 ad libitum observations. In total, 174 species were listed, including 121 land birds and 53 waterbirds. Of these, 11 are considered threatened at regional level. Waterbird richness was significantly higher in the dry season (April to September) than in the rainy season (October to March), whereas land bird richness remained constant. However, land bird richness varied throughout the year, with the highest value in February 2009 (77 species) and the lowest in May 2009 (41 species). The species listed account for $23 \%$ of the total of 745 bird species listed for Rio de Janeiro, and for $49 \%$ of 108 waterbirds recorded for the state.
\end{abstract}

\section{Keywords}

Bird Richness; Neotropical Coastal Lagoons; Northern Rio de Janeiro; Restinga de Jurubatiba; Threatened Wetlands

\section{Introduction}

The Atlantic Forest biome is a priority area for global biodiversity concerns [1]. Within this biome, some of the most productive ecosystems worldwide can be found, including coastal lagoons [2], whose importance for waterbird conservation is recognized at regional and global levels [3]-[5]. Nevertheless, compared to other ecosystems, coastal lagoons are more consistently and intensely exposed to degradation [6] [7]. Also, the avifauna of costal lagoons associated with the Atlantic forest biome has been poorly studied both in Brazil as a whole and in

*Corresponding author. 
Rio de Janeiro state, where most currently published studies are focused on the city of Rio de Janeiro, the state's capital. This scenario becomes worse in northern Rio de Janeiro state, where Pacheco et al. [8] and Tavares et al. [9] pointed to a wide gap in ornithological knowledge. In spite of the lack of data on bird assemblages in northern Rio de Janeiro, few historically important studies have reported pertinent information on birds in the region [10]-[13].

Located in northern Rio de Janeiro, Ribeira lagoon is a coastal water body recently recognized as an Area of Environmental Protection (APA). However, no management plan has been developed for this lagoon, and it has not been studied in detail. This study aims to: 1) provide an inventory of birds recorded in Ribeira lagoon along a year of systematic surveys and additional data collected during opportunistic observations; 2) test if the richness of land and waterbirds differ significantly between the dry and rainy seasons and throughout the year.

\section{Materials and Methods}

\subsection{Study Area}

The present study was conducted in Ribeira lagoon (22 $07^{\prime} 12^{\prime \prime}$ S; $\left.41^{\circ} 27^{\prime} 03^{\prime \prime} \mathrm{W}\right)$, located in Quissamã, a municipality in northern Rio de Janeiro, southeastern Brazilian coast. The study site is a $4 \mathrm{~km}^{2}$ costal lagoon surrounded by marshes and mudflats which may reach $30 \mathrm{~km}^{2}$ during the rainy season (Figure 1). A few remnants of "Restinga" vegetation Forest still exist, but they make up about $2.5 \mathrm{~km}^{2}$ of the study area. Restinga vegetation is described as mosaics of coastal plant communities under high fluvio-marine influence, which are included in Atlantic Forest biome [14]. Although Ribeira lagoon is a protected area, cattle ranching have been expanding steadily in recent years. Presently, about $10 \%$ of its total area (enhanced during the rainy season) is occupied by pastures. Also, this lagoon is located $8 \mathrm{~km}$ away from the Atlantic Ocean coast and is $2 \mathrm{~km}$ distant from Restinga de Jurubatiba National Park. Besides that, it communicates with Feia lagoon, the second largest freshwater lagoon of Brazil, through a mechanical floodgate. Climate in the region has two periods, the dry season (be-

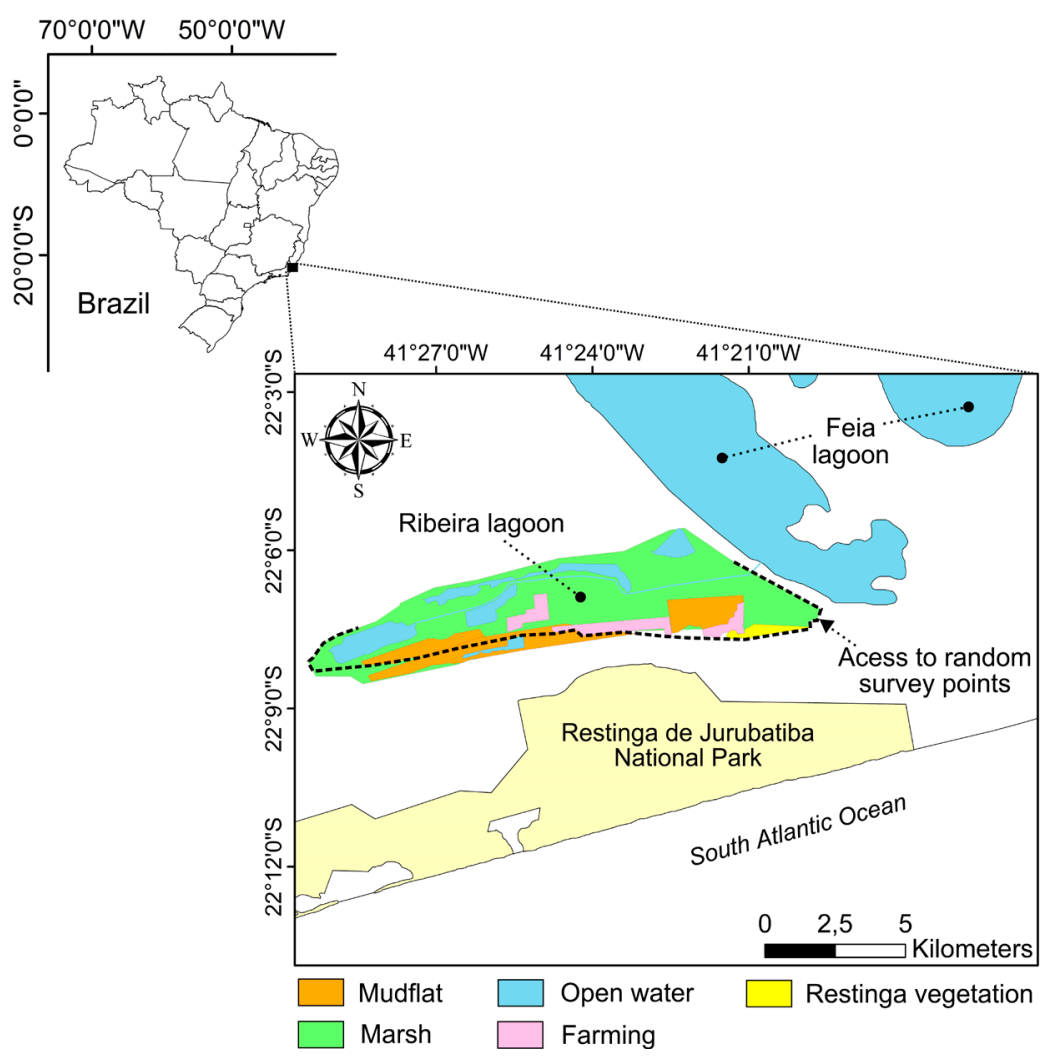

Figure 1. Location of Ribeira lagoon, in northern Rio de Janeiro State, southeastern Brazilian coast. 
tween April and September) and the rainy season (between October and March) [15] [16].

\subsection{Field Surveys}

We carried out monthly excursions in Ribeira lagoon, between August 2008 and July 2009, comprising one complete cycle of climatic seasons and totaling $292 \mathrm{~h}$ of sampling efforts. Each monthly visit lasted three days. Surveys of species presence were conducted mainly between 6 am and $10 \mathrm{am}$, and $3 \mathrm{pm}$ and $7 \mathrm{pm}$. More specifically, our observations were made along 20 semi-random points spaced by at least $300-\mathrm{m}$ intervals along a linear transect around the lagoon. We called this "semi-random" sampling, because points were randomly chosen only in accessible locations [17]. Each point covered a circular area with a 300-m radius. The aim was to guarantee that species would be evenly detected across samples [18]. In addition, we conducted 21 ad libitum observations between November 2010 and May 2013, in order to complement the species' list. This afforded $139 \mathrm{~h}$ of sampling efforts. The birds were observed with $8 \times 42$ binoculars and a $(20-60) \times 80$ spotting scope.

\subsection{Data Analysis}

Differences in richness between dry and rainy seasons were assessed with the Mann-Whitney test for median comparison. We also used the chi-squared test to observe if richness varied significantly among months [19]. The species accumulation curve was obtained by the Jackknife 1 estimator, considering 10,000 randomizations without replacement, using data from August 2008 to July 2009. It should be mentioned that this estimator is suitable for this study design, because it allows working with incidence-based data, since we did not consider abundance data [20]-[22]. Statistical analyses were performed using R 3.0.0 [23].

\section{Results}

We recorded 174 bird species during visits in Ribeira lagoon, including 53 waterbirds and 121 land birds. Of these, 14 bird species were documented exclusively during ad libitum observations. The families with high numbers of species were Tyrannidae (18), Ardeidae (12) and Emberizidae (11). Additionally, of the 174 bird species, 13 (7.5\%) were long-distance migrants, of which 12 are from the Northern Hemisphere and only Tachycineta leucopyga (Figure 2(B)) is from southern areas of South America (Appendix 1). Also, of a total of 13 migrants, seven were Nearctic Shorebirds (53.8\%).

Interestingly, 11 of the species recorded are considered threatened (or near/probably) in Rio de Janeiro: Dendrocygna bicolor, D. autumnalis, (Figure 2(A)) Cairina moschata, Sarkidiornis sylvicola, Platalea ajaja, Ciconia maguari, (Figure 2(F)) Himantopus melanurus (Figure 2(D)), Chroicocephalus cirrocephalus, Amazona rhodocorytha, Mimus gilvus and Sporophila collaris (Figure 2(C)). In addition, A. rhodocorytha is considered threatened at both national and global levels.

With respect to the temporal variation in species richness, the observed monthly richness varied significantly for land birds $\left(\chi^{2}=36.6, \mathrm{P}=0.00021\right)$, but not for waterbirds $\left(\chi^{2}=12.6, \mathrm{P}=0.32\right)$. On the other hand, median values of waterbird richness were higher in the dry season (25 species) than in the rainy season (16 species) (Mann-Whitney test, $\mathrm{P}=0.004$ ), in contrast to the lack of difference for land birds (Mann-Whitney test, $\mathrm{P}=$ 0.62). The highest richness of land birds occurred in February 2009 (77 species), while the lowest value was observed in May (41 species). Moreover, the highest richness of waterbirds occurred in September 2008 (30 species), whereas the lowest was recorded in December 2008 and January 2009 (16 species each) (Appendix 1).

The rarefaction accumulation curve reached a clear asymptote after 12 monthly surveys. The Jackknife 1 index estimated the number of species at $183 \pm 6$ (Figure 3).

\section{Discussion}

Regarding temporal variation, the high richness of waterbirds in the dry season may be due to high availability of shallow waters, which are an advantageous feature considering the feeding habits of many species that occur exclusively during this season [24] [25]. These species include Netta peposaca, D. bicolor, Tigrisoma lineatum, Ixobrychus involucris, Egretta caerulea, P. ajaja, Pandion haliaetus, Gallinula melanops, Calidris melanotos, Phalaropus tricolor and Chroicocephalus cirrocephalus. In fact, during the dry season, water levels fall and the coastal lagoons of the region actually become pools, in a process whose results include the increase in concen- 

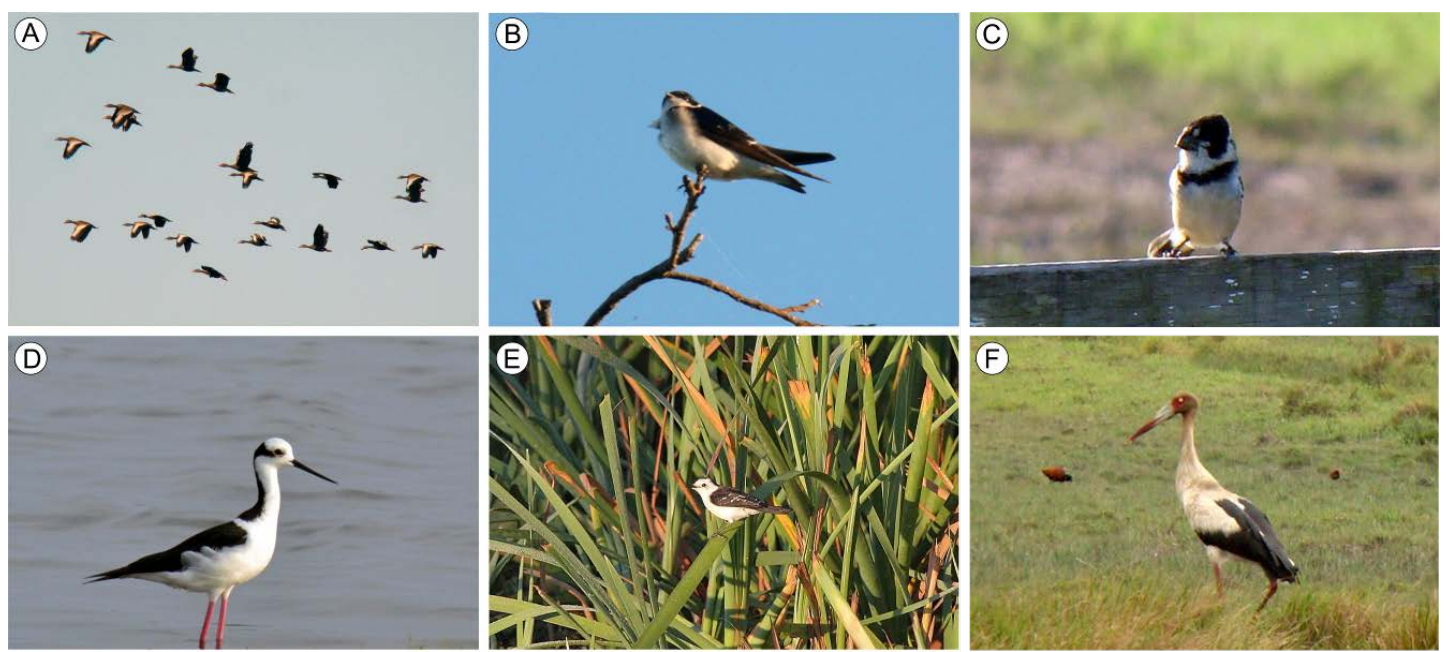

Figure 2. Noteworthy bird records in Ribeira lagoon, northern Rio de Janeiro State, southeastern Brazil. (A) Dendrocygna autumnalis; (B) Tachycineta leucopyga; (C) Sporophilla collaris; (D) Himantopus melanurus; (E) Fluvicola albiventer; (F) Ciconia maguari. Photos by D. C. Tavares, except F. albiventer by Gustavo Henrique.

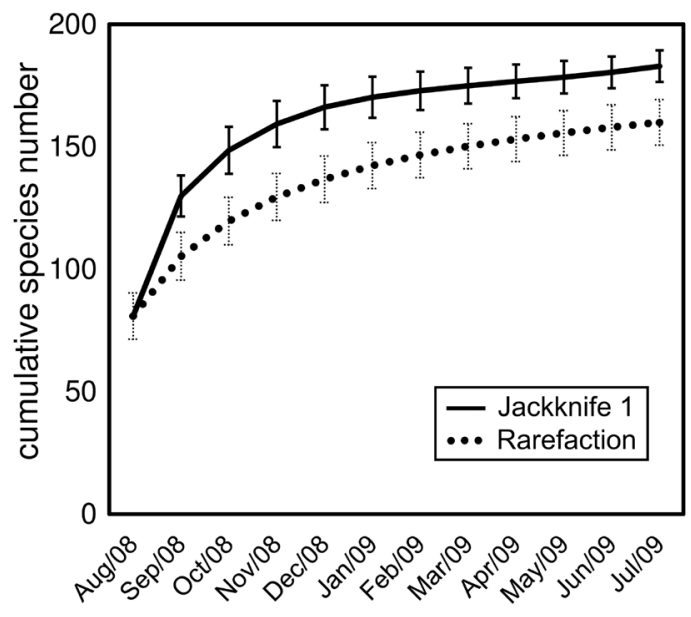

Figure 3. Accumulation curve of bird species recorded in Ribeira lagoon, northern Rio de Janeiro.

trations of preys consumed by waterbirds [9] [16] [26]. On the other hand, non-significant differences in species richness have been observed in other coastal wetlands of southeastern Brazil [27]-[29]. Yet, Ribeira lagoon features high environmental heterogeneity, similarly to the mosaic of wetlands located in Brazilian Pantanal [30] and in Rio Grande do Sul State [31]. So, the temporal changes in environmental characteristics in the site surveyed in the present study may be regarded as more remarkable, when compared to the homogeneous wetlands in southeastern Brazil [27] [28]. Interestingly, Fieker et al. [32] found higher richness of waterbird species during the rainy season, but in grasslands that become much drier in the dry season and therefore do not provide suitable habitats for waterbirds, differently from what was observed in Ribeira lagoon. All in all, the seasonal patterns found in the present study highlight the influence of rainfall in waterbird assembly structure in coastal lagoons in southeastern Brazil.

With respect to land birds, temporal variation occurs to a different scale. Variation takes place on a monthly basis, not between climatic seasons, indicating the intense species turnover in land bird assembly through the year. Thus, future monitoring in the region should be based on surveys carried out on a time basis, at monthly intervals, at least. Differently from our findings, Alves and Pereira [27] reported higher land birds richness during the rainy season and interpreted this difference as result of high availability of insects during this period. In Ribeira lagoon, differences in land bird richness may vary monthly simple because variation in food availability 
(insects and fruits) follows the same time pattern. However, no data about invertebrate and fruit abundance for lagoons in northern Rio de Janeiro are available to allow testing this hypothesis. Further studies considering the role of environmental factors in land birds movements and trade-off in wetlands in northern Rio de Janeiro may contribute to clarify the seasonal richness pattern. In the meantime, we cannot rule out the possibility that one single year-based systematical survey did not suffice as an effort to detect seasonal land bird patterns across different rainfall regimes. Because of interannual variation in richness patterns, long-term data are very important in this sense, as observed for other areas in Brazil [29] [33] [34].

Some species previously listed for nearby wetlands were not recorded in our study. Anas discors, a migrant species from North America, was recorded by Antas et al. [13] in Feia lagoon. These authors and Sick [35] listed Nycticryphes semicollaris in Feia lagoon, while Tavares and Siciliano [5] reported the occurrence of this species in a costal lagoon near Restinga de Jurubatiba National Park, suggesting that it is a resident in the region. We did not record $N$. semicollaris during our surveys, probably due to the cryptic habits of this species. Also, differently from what we expected, Tangara peruviana was not recorded in Ribeira lagoon, although it has been very active during the winter in Restinga de Jurubatiba National Park [36]. So, A. discors, N. semicollaris and T. peruviana could probably occur in Ribeira lagoon, because of its connectivity with Feia lagoon and areas of the Restinga de Jurubatiba National Park.

The richness predicted by the Jackknife 1 estimator (183 \pm 6 species) was slightly greater than the value observed based on both systematic and ad libitum surveys together (174 species). This result reveals the high efficiency of this estimator, considering the sampling methods in the present paper. So, this estimator can be considered a useful tool to compare richness between wetlands surveyed according to different sampling efforts [22] [37]. However, comparisons of this nature are not possible, because the inventories made in similar areas in Rio de Janeiro state do not present species accumulation curves.

Our results can be compared with the information available for the Restinga de Jurubatiba National Park (22 $12^{\prime} 03^{\prime \prime} \mathrm{S}$; $\left.41^{\circ} 28^{\prime} 04^{\prime \prime} \mathrm{W}\right)$, the most similar environment recently inventoried. Alves et al. [36] compiled 96 species in this $680 \mathrm{~km}^{2}$ protected area with 19 coastal lagoons [38]. In terms of waterbirds, 12 species were listed for Restinga de Jurubatiba and only $D$. viduata was mentioned as representative of the Anatidae family. Similarly, only 84 land birds were recorded in Restinga de Jurubatiba. Furthermore, the number of threatened species was higher for Ribeira lagoon (11 species, $6.3 \%$ of the total) than for Restinga de Jurubatiba (2 species, $2.1 \%$ of the total). Nevertheless, a recent continuous and systematic bird monitoring conducted in Restinga de Jurubatiba has found high richness and abundance of migratory and threatened species in Rio de Janeiro state [5]. In addition, Mycteria americana was recently recorded in a lagoon inside Restinga de Jurubatiba [39]. Thus, the differences in richness between the two areas are possibly due to low sampling effort conducted in lagoons where access is difficult in Restinga de Jurubatiba, by Alves et al. [36]. Long-term data are necessary to afford a more accurate comparison between these areas.

When compared to other lowlands exhaustively inventoried in Rio de Janeiro state, Ribeira lagoon shows higher richness. For example, a recent study in $3.80 \mathrm{~km}^{2}$ of lagoons, marshes and forest in Jacarepaguá lowlands (22 58'53" S; 4322'27" W) listed 142 bird species, in contrast with the 172 recorded in Ribeira lagoon [40]. Besides that, Rodrigo de Freitas lagoon ( $22^{\circ} 58^{\prime} 22^{\prime \prime}$ S; $\left.43^{\circ} 12^{\prime} 43^{\prime \prime} \mathrm{W}\right)$ presented only 31 species [27]. This significantly lower richness reflects the high degree of environmental degradation and long-lasting anthropogenic influence in natural hydrological conditions of wetlands of central coast of Rio de Janeiro, in comparison with wetlands in the north of the State.

Regarding the occurrence of threatened birds in the study site, Dendrocygna autumnalis was previously reported by Antas et al. [13] for Feia lagoon, although a few records were made in the central coast of Rio de Janeiro, an extensively surveyed region [41]-[43]. In the present study, this species was recorded in $92 \%$ of surveys and in flocks of up to 300 individuals. These findings confirm a recent geographic expansion of $D$. autumnalis in Rio de Janeiro [42], and highlight the need for the adoption of conservation strategies for Ribeira lagoon. Dendrocygna bicolor is rare in the state, though it has been recorded in the municipality of Rio de Janeiro [44]; however, it was never recorded in northern Rio de Janeiro. Low numbers of Sporophila collaris were observed in the Poço das Antas Biological Reserve, Silva Jardim [45], but this species was frequently recorded in the marsh vegetation dominated by Typha domingensis in Ribeira lagoon. Interestingly, C. maguari, M. americana and C. moschata, which are considered extinct in the municipality of Rio de Janeiro [46], were recorded in the study site. It should be emphasized that remnants of natural wetlands in northern Rio de Janeiro, such as Ribeira lagoon, may represent remarkable habitat remnants for D. bicolor, D. autumnalis, C. maguari and S. collaris, 
whose populations are under threat at state level [26] [47].

Of the total number of species recorded, Passer domesticus, Estrilda astrild and Cariama cristata were introduced. The first two originate from the European and African continents, and were introduced in Brazil in the early 1900's, expanding their distribution ranges using their forage and reproductive skills [48]. The third descends from individuals introduced in the Restinga de Jurubatiba National Park by farmers [49]. Also, Paroaria dominicana, typical of the dry Caatinga biome, was probably introduced due to traffic, as observed in other areas in Brazil [50]-[52]. On the other hand, some relatively recent cases of invasive species [53] in Ribeira lagoon are noteworthy: Bubulcus ibis, Herpetotheres cachinnans, Patagioenas picazuro, Mimus saturninus, Paroaria dominicana, Fluvicola nengeta, Fluvicola albiventer (Figure 2(D)) and Theristicus caudatus. Bubulcus ibis is native to the African continent [54], and its first record in Brazil was made in 1964 by Sick [55], when it started to expand its distribution range, using pastures. Both $F$. nengeta and F. albiventer inhabit wet environments associated with open areas [51]. The first is expanding its geographic range towards the south Brazil, benefiting from the expansion of open areas due to deforestation [50], and seems to have colonized Rio de Janeiro around the 1950's [44]. The second occurs in large river basins, mainly in northeastern Brazil, Minas Gerais, Paraná and São Paulo states. Until recently it was presumed that the species did not occur in the states of Espírito Santo and Rio de Janeiro, with a spatial gap between Bahia and São Paulo [56]. However, the present record, made on the $3^{\text {rd }}$ of May 2010, together with the breeding report in a lagoon in "Campos dos Goytacazes" [57], suggests that this species may be expanding its range in Rio de Janeiro in response to forest clearing. The record of Theristicus caudatus represents a special case of rapid colonization of open areas in the State, possibly due to deforestation [58].

The documented record of $T$. leucopyga represents the first for Rio de Janeiro state, and prompted the inclusion of this species in the bird list of the state [59]. On the $11^{\text {th }}$ of August 2008, a large flock of about 6000 swallows was sighted flying and roosting on the banks of the lagoon. Likewise, at least 2000 individuals were recorded on the $18^{\text {th }}$ of June 2009. Although it is known that T. leucopyga breeds from Chile to Argentina and moves to Brazil during the winter [56], few records of the species in coastal areas of the country have been published.

The list of species we have provided for Ribeira lagoon includes 23\% of the total of 745 bird species listed for Rio de Janeiro, as well as $49 \%$ of 108 inland waterbirds recorded for the state. In this context, the high number of species recorded, besides the eleven threatened species at state level (nine waterbirds), highlights the importance of this natural wetland. Yet, Ribeira lagoon is under intense pressure due to the digging of canals to claim land for agriculture, sewage discharges, hunting and human-induced fire, such as observed in other lagoons in northern Rio de Janeiro. Thus, further studies should evaluate waterbirds habitat use in this coastal lagoon and other similar environments, in order to improve restoration and management strategies.

\section{Acknowledgements}

The authors are grateful to the municipal authorities of Quissamã and ICMBio and to the Ecology and Natural Resources Post-graduation Program, State University of Northern Rio de Janeiro. Also, authors thank to J.F. Pacheco for kindly providing relevant literature; to A.B.A. Soares for helpful comments on the study and to G. Brito and A. Zillikens for reviewing early versions of the manuscript. This study is part of the wetland birds monitoring program in the northern coast of the Rio de Janeiro State. S. S. is supported by Conselho Nacional de Desenvolvimento Científico e Tecnológico-CNPq (Processo no. 301544/2008-5). D.C.T. is supported by Coordenação de Aperfeiçoamento de Pessoal de Nível Superior-CAPES.

\section{References}

[1] Myers, N., Mittermeier, R.A., Mittermeier, C.G., Fonseca, G.A.B. and Kent, J. (2000) Biodiversity Hotspots for Conservation Priorites. Nature, 403, 853-858. http://dx.doi.org/10.1038/35002501

[2] Veloso, R.B., Rangel Filho, A.L.R. and Lima, J.C.A. (1991) Classificação da Vegetação Brasileira Adaptada a um Sistema Universal. IBGE, Rio de Janeiro.

[3] Esteves, F.A., Caliman, A., Santangelo, J.M., Guariento, R.D., Farjalla, V.F. and Bozelli, R.L. (2008) Neotropical Coastal Lagoons: An Appraisal of Their Biodiversity, Functioning, Threats and Conservation Management. Brazilian Journal of Biology, 68, 967-981. http://dx.doi.org/10.1590/S1519-69842008000500006 
[4] Dias, R.A., Gianuca, D., Gianuca, A.T., Junior, A.G., Chiaffitelli, R. and Ferreira, W.L.S. (2011) Estuário da Lagoa dos Patos. In: Valente, R.M., Silva, J.M.C., Straube, F.C. and Nascimento, J.L.X., Eds., Conservação de aves migratórias neárticas no Brasil, Conservação Internacional, Belém, 335-341.

[5] Tavares, D.C. and Siciliano, S. (2013) An Inventory of Wetland Non-Passerine Birds along a Southeastern Brazilian Coastal Area. Journal of Threatened Taxa, 5, 4586-4597. http://dx.doi.org/10.11609/JoTT.03424.4586-97

[6] World Resources Institute (2005) Ecosystems and Human Well-Being: Biodiversity Synthesis. World Resources Institute, Washington DC.

[7] Thomas, P.J., Martin, P. and Boutin, C. (2011) Bush, Bugs, and Birds; Interdependency in a Farming Landscape. Open Journal of Ecology, 1, 9-23. http://dx.doi.org/10.4236/oje.2011.12002

[8] Pacheco, J.F., Parrini, R., Fonseca, P.S.M., Whitney, B.M. and Maciel, N.C. (1996) Novos Registros de aves para o Estado do Rio de Janeiro: Região Norte. Atualidades Ornitológicas, 72, 10-12.

[9] Tavares, D.C., Moura, J.F. and Siciliano, S. (2012) As aves das Áreas Úmidas. Ciência Hoje, 50, 42-47.

[10] Wied-Neuwied, M. (1821) Reise nach Brasilien in den Jahren 1815 bis 1817. Heinrich Ludwig Bronner, Frankfurt.

[11] Reys, M.M.C. (1997) Manuscritos de Manoel Martinz do Couto Reys, 1785. Arquivo Público do Estado do Rio de Janeiro, Rio de Janeiro.

[12] Pelzeln, A. (1871) Zur Ornithologie Brasiliens: Resultate von Johann Natterers Reisen in den Jahren 1817 bis 1835. A. Picher's Witwe \& Sohn, Viena. http://dx.doi.org/10.5962/bhl.title.3654

[13] Antas, P.T.Z., Silva, F., Alves, M.A.S. and Lara-Resende, S.M. (1986) Brazil. In: Scott, D.A. and Carbonell, M., Eds., A Directory of Neotropical Wetlands, International Union for Conservation of Nature and Natural Resources, Cambridge, 60-104.

[14] Assumpção, J. and Nascimento, M.T. (2000) Estrutura e composição florística de quatro formações vegetais de restinga no complexo lagunar Grussaí/Iquipari, São João da Barra, RJ, Brasil. Acta Botanica Brasilica, 14, 301-315. http://dx.doi.org/10.1590/S0102-33062000000300007

[15] Carmouze, J.P., Knoppers, B. and Vasconcelos, P. (1991) Metabolism of a Subtropical Brazilian Lagoon. Biogeochemistry, 14, 129-148. http://dx.doi.org/10.1007/BF00002902

[16] Macedo-Soares, P.H.M., Petry, A.C., Farjalla, V.F. and Camaraschi, E.P. (2010) Hydrological Connectivity in a Coastal Inland Systems: Lessons from a Neotrpical Fish Metacommunity. Ecology of Freshwater, 19, 7-18. http://dx.doi.org/10.1111/j.1600-0633.2009.00384.x

[17] Bibby, C., Martin, J. and Marsden, S. (2000) Expedition Field Techniques: Bird Surveys. BirdLife International, Cambridge.

[18] Hutto, R.L., Pletschet, S.M. and Hendricks, P. (1986) A Fixed-Radius Point Count Method for Nonbreeding and Breeding Season Use. The Auk, 103, 593-602.

[19] Brandolin, P., Martori, R. and Ávalos, M. (2007) Variaciones Temporales de los Ensambles de aves de la Reserva Natural de Fauna Laguna La Felipa (Córdoba, Argentina). Hornero, 22, 1-8.

[20] Heltshe, J.F. and Forrestor, N.E. (1979) Estimating Species Richness Using the Jackknife Procedure. Biometrics, 39, 1-11. http://dx.doi.org/10.2307/2530802

[21] Palmer, M.W. (1990) The Estimation of Species Richness by Extrapolation. Ecology, 71, 1195-1198. http://dx.doi.org/10.2307/1937387

[22] Magurran, A.E. (2011) Medindo a Diversidade Biológica. Ed. da UFPR, Curitiba.

[23] Ihaka, R. and Gentleman, R. (1996) R: A Language for Data Analysis and Graphics. Journal of Computational and Graphical Statistics, 5, 299-314.

[24] Ntiamoa-Baidu, Y., Piersma, T., Wiersma, P., Poot, M., Battley, P. and Gordon, C. (1998) Water Depth Selection, Daily Feeding Routines and Diets of Waterbirds in Coastal Lagoons in Ghana. IBIS, 140, 89-103. http://dx.doi.org/10.1111/j.1474-919X.1998.tb04545.x

[25] Ma, Z., Cai, Y., Li, B. and Chen, J. (2010) Managing Wetland Habitats for Waterbirds: An International Perspective. Wetlands, 30, 15-27. http://dx.doi.org/10.1007/s13157-009-0001-6

[26] Tavares, D.C., Moura, J.F., Amorim, C.E. and Siciliano, S. (2013) Distribution and Abundance of the Grey-Headed Gull Chroicocephalus cirrocephalus (Vieillot, 1818) in Rio de Janeiro, Southeastern Brazilian Coast. Brazilian Journal of Ornithology, 21, 168-175.

[27] Alves, M.A.S. and Pereira, E.F. (1998) Richness, Abundance and Seasonality of Bird Species in a Lagoon of an Urban Area (Lagoa Rodrigo de Freitas) of Rio de Janeiro, Brazil. Ararajuba, 6, 110-116.

[28] Rubim, P. (2013) Sazonalidade na Assembleia de aves Aquáticas em uma Lagoa Marginal do Rio Mogi Guaçu, Estado de São Paulo, Brasil. Revista Brasileira de Ornitologia, 21, 10-15. 
[29] Rodrigues, M. and Michelin, V.B. (2005) Riqueza e Diversidade de aves Aquáticas de uma Lagoa Natural no Sudeste do Brasil. Revista Brasileira de Zoologia, 22, 928-935. http://dx.doi.org/10.1590/S0101-81752005000400019

[30] Accordi, I.A. and Hartz, S.M. (2006) Distribuição Espacial e Sazonal da Avifauna em uma Área Úmida Costeira do sul do Brasil. Revista Brasileira de Ornitologia, 2, 117-135.

[31] Oliveira, D.M.M. (2006) Efeitos Bióticos e Abióticos de Ambientes Alagáveis nas Assembléias de aves Aquáticas e Piscívoras no Pantanal, Brasil. Ph.D. Thesis, Universidade Federal do Amazonas, Manaus.

[32] Fieker, C.Z., Reis, M.G. and Dias Filho, M.M. (2013) Structure of Bird Assemblages in Dry and Seasonally Flooded Grasslands in Itirapina Ecological Station, São Paulo state. Brazilian Journal of Biology, 73, 91-101. http://dx.doi.org/10.1590/S1519-69842013000100011

[33] Silveira, L.F. and Uezu, A. (2011) Checklist das aves do Estado de São Paulo, Brasil. Biota Neotropica, 11, 83-110. http://dx.doi.org/10.1590/S1676-06032011000500006

[34] Accordi, I.A. (2010) Pesquisa e Conservação de aves em Áreas Úmidas. In: Von Matter, S., Straube, F.C., Accordi, I.A., Piacentini, V. and Cândido Júnior, J.F., Eds., Ornitologia e Conservação: Ciência Aplicada, Técnicas de Pesquisa e Levantamento, Technical Books, Rio de Janeiro, 191-219

[35] Sick, H. (1962) Die Buntschnepfe, Nycticryphes semicollaris in Brasilien. Journal für Ornithologie, 103, 102-107. http://dx.doi.org/10.1007/BF01670852

[36] Alves, M.A.S., Storni, A., Almeida, E.M., Gomes, V.S.M., Oliveira, C.H.P., Marques, R.V. and Vecchi, M. (2004) A Comunidade de Aves na Restinga de Jurubatiba. In: Rocha, C.F.D., Esteves, F.A. and Scarano, F.R., Eds., Pesquisas de Longa Duração na Restinga de Jurubatiba: Ecologia, História Natural e Conservação, Rima, Rio de Janeiro, 199-214.

[37] Ugland, K.I., Gray, J.S. and Ellingsen, K.E. (2003) The Species-Accumulation Curve and Estimation of Richness. Journal of Animal Ecology, 72, 888-897. http://dx.doi.org/10.1046/j.1365-2656.2003.00748.x

[38] Enrich-Prast, A., Bozelli, R.L., Esteves, F.A. and Meirelles, F.P. (2004) Lagoas Costeiras da Restinga de Jurubatiba: Descrição de Suas Variáveis Limnológicas. In: Rocha, C.F.D., Esteves, F.A. and Scarano, F.R., Eds., Pesquisas de Longa Duração na Restinga de Jurubatiba, RiMa, São Carlos, 245-253.

[39] Tavares, D.C. and Siciliano, S. (2013) Registro Documentado de Cabeça-Seca Mycteria americana no Norte Fluminense Após 18 Anos Sem Relatos de Ocorrência. Atualidades Ornitológicas, 172, 18-21.

[40] Mallet-Rodrigues, F., Alves, V.S., Noronha, M.L.M.N., Serpa, G.A., Soares, A.B.A., Couto, G.S., Maciel, E., Madeira, S. and Draghi, J. (2008) Aves da Baixada de Jacarepaguá, Município do Rio de Janeiro, Estado do Rio de Janeiro. Revista Brasileira de Ornitologia, 16, 221-231.

[41] Magnanini, A. and Coimbra Filho, A.F. (1964) Avifauna da Reserva Biológica de Jacarepaguá (Est. da Guanabara, Brasil). Vellozia, 1, 147-166.

[42] Oliveira, A.H. and Pacheco, J.F. (2010) Primeiro Registro Documentado Para o Município do Rio de Janeiro e Comentários Sobre Dendrocygna autumnalis (Anseriformes: Anatidae) Acerca de Sua Recente Expansão Geográfica. Atualidades Ornitológicas, 158, 14-15.

[43] Camacho, I. and Pimentel, L.M.S. (2012) Registros Reprodutivos da Asa-Branca, Dendrocygna autumnalis, no Estado do Rio de Janeiro, Brasil. Atualidades Ornitológicas, 169, 6-8.

[44] Sick, H. and Pabst, L.F. (1968) As Aves do Rio de Janeiro (Guanabara), Lista Sistemática Anotada. Arquivo do Museu Nacional, 53, 99-160.

[45] Pacheco, J.F., Astor, I.N.C. and Cesar, C.B. (2010) Avifauna da Reserva Biológica de Poço das Antas, Silva Jardim, RJ. Atualidades Ornitológicas, 157, 55-74.

[46] Maciel, E. (2009) Aves do Município do Rio de Janeiro. Technical Books, Rio de Janeiro.

[47] Tavares, D.C. and Siciliano, S. (2013) Notes on Records of Ciconia maguari (Gmelin, 1789) (Aves, Ciconiidae) on Northern Rio de Janeiro State, Southeast Brazil. Pan-American Journal of Aquatic Sciences, 8, 352-357.

[48] Bruno, S.F. and Bard, V.T. (2012) Exóticos Invasores. Editora da UFF, Niterói.

[49] Gonzaga, L.P., Castilgioni, G.D.A. and Reis, H.B.R. (2000) Avifauna das Restingas do Sudeste: Estado do Conhecimento e Potencial Para Futuros Estudos. In: Esteves, F.A. and Lacerda, L.D., Eds., Ecologia de Restingas e Lagoas Costeiras, NUPEM/UFRJ, Macaé, 151-163.

[50] Willis, E.O. (1991) Expansão Geográfica de Netta erythrophthalma, Fluvicola nengeta e Outras de Zonas Abertas com a “desertificação” Antrópica em São Paulo. Ararajuba, 2, 101-102.

[51] Sick, H. (1997) Ornitologia Brasileira. Nova Fronteira, Rio de Janeiro.

[52] Nascimento, M. and Alves, E. (2007) Aves no Rio grande do Sul: A Problemática do Tráfico, Educação e Conscientização Ambiental. Pallotti, Santa Maria. 
[53] Sakai, A., Allendorf, F.W., Holt, J.S., Lodge, D.M., Molofsky, J., With, K.A., Baughman, S., Cabin, R.J., Cohen, J.E., Ellstrand, N.C., McCauley, D.E., O’Neil, P., Parker, I.M., Thompson, J.N. and Weller, S.G. (2001) The Population Biology of Invasive Species. Annual Review of Ecology and Systematics, 32, 305-332. http://dx.doi.org/10.1146/annurev.ecolsys.32.081501.114037

[54] Rice, D.W. (1956) Dynamics of Range Expansion of Cattle Egrets in Florida. Auk, 73, 259-266.

[55] Sick, H. (1965) Bulbucus ibis /(L) na Ilha de Marajó, Pará: Garça Ainda não Registrada no Brasil. Anais da Academia Brasileira de Ciências, 37, 567-570.

[56] Amorim, J.F. and Piacentini, V.Q. (2007) Novas Áreas de Ocorrência de Três Passeriformes no sul do Brasil. Lundiana, 8, 69-73.

[57] Lima, L.M. and Pacheco, J.F. (2006) A Lavadeira-da-Cara-Branca, Fluvicola albiventer, Uma Nova Espécie Para o Estado do Rio de Janeiro e um Inusitado Símbolo da Degradação Ambidental. Proceedings of the XIV Brazilian Ornithological Congress, Ouro Preto, Minas Gerais, 2-6 July 2006, 36.

[58] Serpa, G.A., Pacheco, J.F., Lima, L.M.L., Parrini, R., Pimentel, L.S.P., Pinto, M.F.R., Antonini, R.D., Rajão, H., Oliveira, A.H., Tavares, D.C., Siciliano, S., Mallet-Rodrigues, F., Luz, H.R., Ribenboim, L.C., Soares, B.R. and Crud, N. (2010) A Curicaca, Theristicus caudatus (Ciconiiformes: Threskiornithidae) no Estado do Rio de Janeiro: Uma Revisão dos Registros e Novas Observações. Atualidades Ornitológicas Online, 153, 62-68.

[59] Gagliardi, R. (2011) Lista de Aves do Estado do Rio de Janeiro. http://www.ceo.org.br/listas_de_aves/RJ-Gagliardi.pdf

[60] CBRO. (2011) Lista de Aves do Brasil. http://www.cbro.org.br 


\section{Appendix 1}

Appendix 1. Birds recorded in Ribeira lagoon, northern Rio de Janeiro, southeastern Brazil. Legend. Regional threat status (RJ, Alves et al. 2000): $\mathrm{Ne}=$ near (or probably) endangered, $\mathrm{Vu}=$ vulnerable and $\mathrm{En}=$ endangered. Group: $\mathrm{W}=\mathrm{Waterbirds}$, $\mathrm{L}=$ Land birds. Migratory status: VN = Nearctic migrant, VS = Southern migrant and $\mathrm{R}=$ Resident. The circles indicate the presence of species in each month during systematical surveys and triangles indicate species recorded only during ad libitum surveys. Grey area indicates the rainy season. Taxonomy follows the Brazilian Committee of Ornithological Records [60].

\begin{tabular}{|c|c|c|c|c|c|c|c|c|c|c|c|c|c|c|}
\hline \multirow{2}{*}{ Family/Species } & \multirow{2}{*}{ Group } & \multirow{2}{*}{ Status } & \multicolumn{12}{|c|}{ Months } \\
\hline & & & A & $\mathbf{S}$ & $\mathbf{O}$ & $\mathbf{N}$ & D & $\mathbf{J}$ & $\mathbf{F}$ & $\mathbf{M}$ & A & $\mathbf{M}$ & $\mathbf{J}$ & $\mathbf{J}$ \\
\hline \multicolumn{15}{|l|}{ Anatidae } \\
\hline Dendrocygna bicolor (Vieillot, 1816) ${ }^{\mathbf{V u}}$ & $\mathrm{W}$ & $\mathrm{R}$ & & & & & & & & & $\bullet$ & & & \\
\hline Dendrocygna viduata (Linn., 1766) & $\mathrm{W}$ & $\mathrm{R}$ & $\bullet$ & $\bullet$ & $\bullet$ & $\bullet$ & $\bullet$ & $\bullet$ & $\bullet$ & $\bullet$ & $\bullet$ & $\bullet$ & $\bullet$ & $\bullet$ \\
\hline Dendrocygna autumnalis (Linn., 1758) & $\mathrm{W}$ & $\mathrm{R}$ & & $\bullet$ & $\bullet$ & $\bullet$ & $\bullet$ & $\bullet$ & $\bullet$ & $\bullet$ & $\bullet$ & $\bullet$ & $\bullet$ & $\bullet$ \\
\hline Cairina moschata (Linnaeus, 1758) & $\mathrm{W}$ & $\mathrm{R}$ & & $\Delta$ & & & & & & & & & & \\
\hline Sarkidiornis sylvicola Iher. \& Iher., $1907^{\text {En }}$ & $\mathrm{W}$ & $\mathrm{R}$ & & $\boldsymbol{\Delta}$ & & & & & & & & & & \\
\hline Amazonetta brasiliensis (Gmelin, 1789) & $\mathrm{W}$ & $\mathrm{R}$ & $\bullet$ & $\bullet$ & $\bullet$ & $\bullet$ & $\bullet$ & $\bullet$ & $\bullet$ & $\bullet$ & $\bullet$ & $\bullet$ & $\bullet$ & $\bullet$ \\
\hline Anas bahamensis Linnaeus, 1758 & $\mathrm{~W}$ & $\mathrm{R}$ & $\bullet$ & $\bullet$ & $\bullet$ & & $\bullet$ & & & $\bullet$ & $\bullet$ & $\bullet$ & $\bullet$ & $\bullet$ \\
\hline Netta erythrophthalma (Wied, 1832) & $\mathrm{W}$ & $\mathrm{R}$ & & $\bullet$ & $\bullet$ & & & & & & & $\bullet$ & $\bullet$ & $\bullet$ \\
\hline Netta peposaca (Vieillot, 1816) & $\mathrm{W}$ & $\mathrm{R}$ & $\bullet$ & & & & & & & & & & $\bullet$ & $\bullet$ \\
\hline Nomonix dominica (Linnaeus, 1766) & $\mathrm{W}$ & $\mathrm{R}$ & $\bullet$ & & $\bullet$ & & & & & & & $\bullet$ & $\bullet$ & $\bullet$ \\
\hline \multicolumn{15}{|l|}{ Podicipedidae } \\
\hline Podilymbus podiceps (Linnaeus, 1758) & $\mathrm{W}$ & $\mathrm{R}$ & $\bullet$ & $\bullet$ & $\bullet$ & & & $\bullet$ & & & $\bullet$ & $\bullet$ & $\bullet$ & $\bullet$ \\
\hline Tachybaptus dominicus (Linnaeus, 1766) & $\mathrm{W}$ & $\mathrm{R}$ & $\bullet$ & $\bullet$ & & & & & & & & & & $\bullet$ \\
\hline \multicolumn{15}{|l|}{ Ciconiidae } \\
\hline Ciconia maguari (Gmelin, 1789) & $\mathrm{W}$ & $\mathrm{R}$ & $\bullet$ & $\bullet$ & & & & & $\bullet$ & & & & & \\
\hline Mycteria americana Linnaeus, 1758 & $\mathrm{~W}$ & $\mathrm{R}$ & & & & & & $\Delta$ & & & & & & \\
\hline \multicolumn{15}{|l|}{ Phalacrocoracidae } \\
\hline Phalacrocorax brasilianus (Gm., 1789) & W & $\mathrm{R}$ & $\bullet$ & $\bullet$ & $\bullet$ & $\bullet$ & & & & & $\bullet$ & $\bullet$ & $\bullet$ & $\bullet$ \\
\hline \multicolumn{15}{|l|}{ Ardeidae } \\
\hline Tigrisoma lineatum (Boddaert, 1783) & $\mathrm{W}$ & $\mathrm{R}$ & & & & & & & & & $\bullet$ & & $\bullet$ & $\bullet$ \\
\hline Botaurus pinnatus (Wagler, 1829) & $\mathrm{W}$ & $\mathrm{R}$ & & $\bullet$ & $\bullet$ & & & & $\bullet$ & & & & & $\bullet$ \\
\hline Ixobrychus exilis (Gmelin, 1789) & $\mathrm{W}$ & $\mathrm{R}$ & & & & & & & $\bullet$ & & & & & \\
\hline Ixobrychus involucris (Vieillot, 1823) & $\mathrm{W}$ & $\mathrm{R}$ & $\bullet$ & $\bullet$ & & & & & & & & & $\bullet$ & $\bullet$ \\
\hline Nycticorax nycticorax (Linnaeus, 1758) & $\mathrm{W}$ & $\mathrm{R}$ & & & & & & & & & $\bullet$ & & & $\bullet$ \\
\hline Butorides striata (Linnaeus, 1758) & $\mathrm{W}$ & $\mathrm{R}$ & $\bullet$ & $\bullet$ & $\bullet$ & $\bullet$ & $\bullet$ & $\bullet$ & & & $\bullet$ & $\bullet$ & $\bullet$ & $\bullet$ \\
\hline Bubulcus ibis (Linnaeus, 1758) & $\mathrm{W}$ & $\mathrm{R}$ & $\bullet$ & $\bullet$ & $\bullet$ & $\bullet$ & $\bullet$ & $\bullet$ & $\bullet$ & $\bullet$ & $\bullet$ & $\bullet$ & $\bullet$ & $\bullet$ \\
\hline Ardea cocoi Linnaeus, 1766 & $\mathrm{~W}$ & $\mathrm{R}$ & & $\bullet$ & $\bullet$ & $\bullet$ & $\bullet$ & $\bullet$ & & $\bullet$ & & & $\bullet$ & $\bullet$ \\
\hline Ardea alba Linnaeus, 1758 & $\mathrm{~W}$ & $\mathrm{R}$ & $\bullet$ & $\bullet$ & $\bullet$ & $\bullet$ & $\bullet$ & $\bullet$ & $\bullet$ & $\bullet$ & $\bullet$ & $\bullet$ & $\bullet$ & $\bullet$ \\
\hline Syrigma sibilatrix (Temminck, 1824) & $\mathrm{W}$ & $\mathrm{R}$ & & & & & & & $\bullet$ & & & & & \\
\hline Egretta thula (Molina, 1782) & $\mathrm{W}$ & $\mathrm{R}$ & $\bullet$ & $\bullet$ & $\bullet$ & $\bullet$ & $\bullet$ & $\bullet$ & $\bullet$ & $\bullet$ & $\bullet$ & $\bullet$ & $\bullet$ & $\bullet$ \\
\hline Egretta caerulea (Linnaeus, 1758) & $\mathrm{W}$ & $\mathrm{R}$ & $\bullet$ & $\bullet$ & $\bullet$ & $\bullet$ & & & & & $\bullet$ & & $\bullet$ & $\bullet$ \\
\hline \multicolumn{15}{|l|}{ Threskiornithidae } \\
\hline Theristicus caudatus (Boddaert, 1783) & $\mathrm{W}$ & $\mathrm{R}$ & $\Delta$ & & & & & & & & & & & \\
\hline Platalea ajaja Linnaeus, $1758^{\mathrm{Ne}}$ & $\mathrm{W}$ & $\mathrm{R}$ & & & & & & & & & & & $\bullet$ & \\
\hline
\end{tabular}




\section{Continued}

\section{Pandionidae}

Pandion haliaetus (Linnaeus, 1758)

\section{Accipitridae}

Elanoides forficatus (Linnaeus, 1758)

Elanus leucurus (Vieillot, 1818)

Rostrhamus sociabilis (Vieillot, 1817)

Geranospiza caerulescens (Vieillot, 1817)

Heterospizias meridionalis (Latham, 1790)

Rupornis magnirostris (Gmelin, 1788)

Parabuteo unicinctus (Temminck, 1824)

Geranoaetus albicaudatus (Vieillot, 1816)

Buteo brachyurus Vieillot, 1816

\section{Falconidae}

Caracara plancus (Miller, 1777)

Milvago chimachima (Vieillot, 1816)

Herpetotheres cachinnans (Linnaeus, 1758)

Falco sparverius Linnaeus, 1758

Falco femoralis Temminck, 1822

Falco peregrinus Tunstall, 1771

\section{Aramidae}

Aramus guarauna (Linnaeus, 1766)

\section{Rallidae}

Aramides cajanea (Statius Muller, 1776)

Aramides saracura (Spix, 1825)

Laterallus melanophaius (Vieillot, 1819)

Porzana albicollis (Vieillot, 1819)

Pardirallus nigricans (Vieillot, 1819)

Gallinula galeata (Linnaeus, 1758)

Porphyrio martinica (Linnaeus, 1766)

Gallinula melanops (Vieillot, 1819)

\section{Cariamidae}

Cariama cristata (Linnaeus, 1766)

\section{Charadriidae}

Vanellus chilensis (Molina, 1782)

Charadrius semipalmatus Bon., 1825

Charadrius collaris Vieillot, 1818

\section{Recurvirostridae}

Himantopus melanurus Vieillot, $1817^{\mathrm{Ne}}$

\section{Scolopacidae}

Tringa solitaria Wilson, 1813
W VN
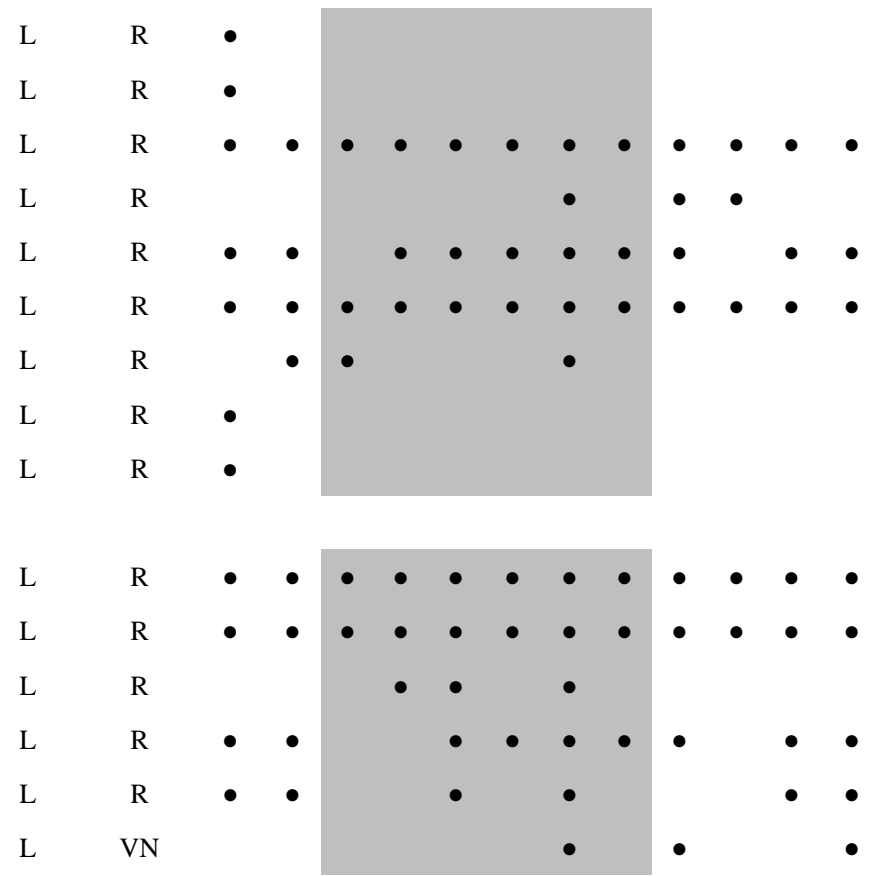

W

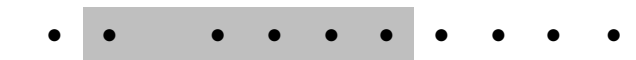

W $\quad \mathrm{R}$

W R

W R

W R

W $\mathrm{R}$

W R

W

W

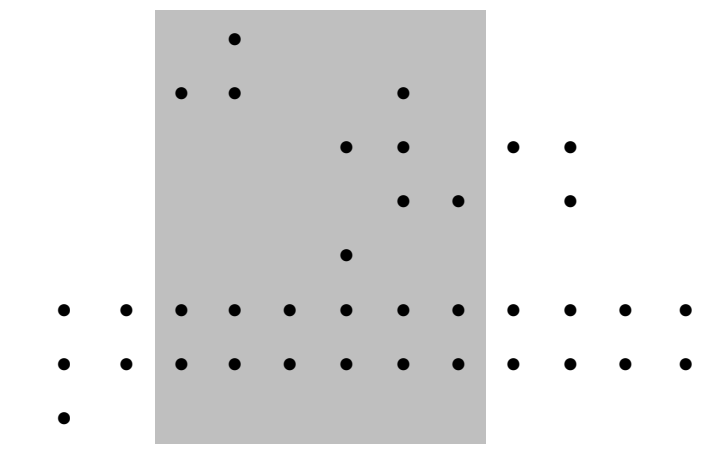

L $\quad$ R

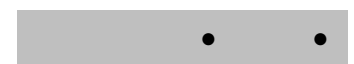

W

W

W

政

R

VN

R

W

R 


\section{Continued}

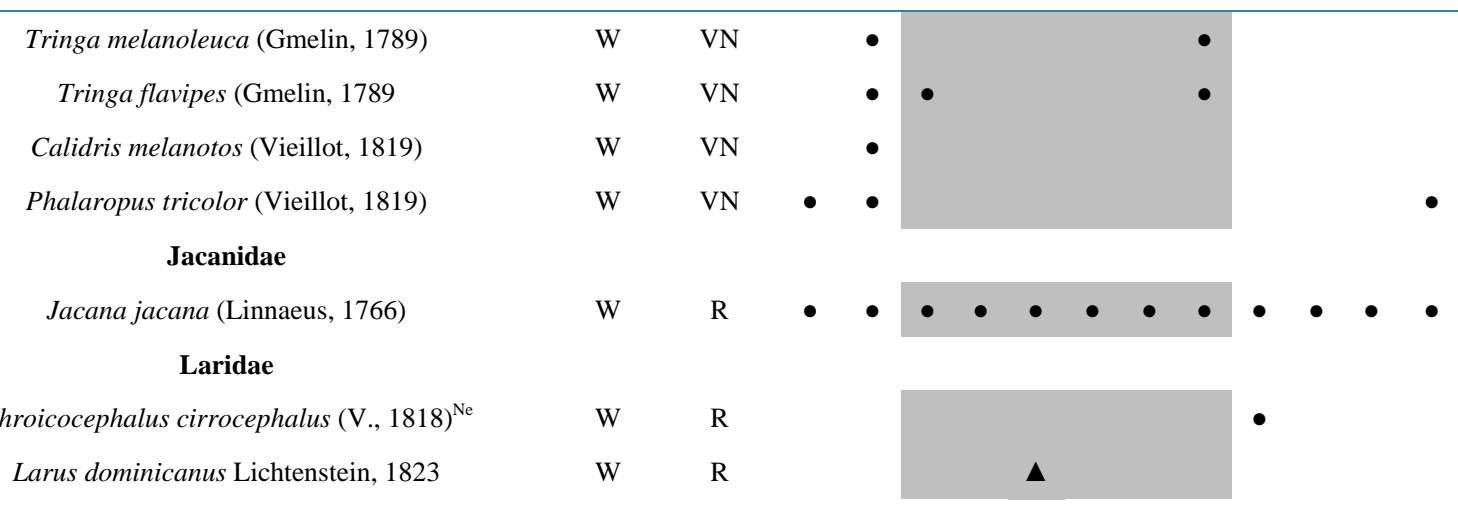

\section{Columbidae}

Columbina minuta (Linnaeus, 1766)

Columbina talpacoti (Temminck, 1811)

Columbina picui (Temminck, 1813)

Columba livia Gmelin, 1789

Patagioenas picazuro (Temminck, 1813)

Patagioenas cayennensis (Bonna., 1792)

Zenaida auriculata (Des Murs, 1847)

Leptotila verreauxi Bonaparte, 1855

\section{Psittacidae}

Pionus maximiliani (Kuhl, 1820)

Amazona rhodocorytha (Salv., 1890) ${ }^{\mathrm{Vu}}$

\section{Cuculidae}

\begin{abstract}
Piaya cayana (Linnaeus, 1766)
Crotophaga major Gmelin, 1788

Crotophaga ani Linnaeus, 1758

Guira guira (Gmelin, 1788)
\end{abstract}

Tapera naevia (Linnaeus, 1766)

\section{Tytonidae}

Tyto alba (Scopoli, 1769)

\section{Strigidae}

Athene cunicularia (Molina, 1782)

\section{Caprimulgidae}

Hydropsalis albicollis (Gmelin, 1789)

Hydropsalis torquata (Gmelin, 1789)

Chordeiles nacunda (Vieillot, 1817)

Chordeiles minor (Forster, 1771)

Chordeiles acutipennis (Hermann, 1783)

\section{Apodidae}

Streptoprocne zonaris (Shaw, 1796)

Streptoprocne biscutata (Sclater, 1866)

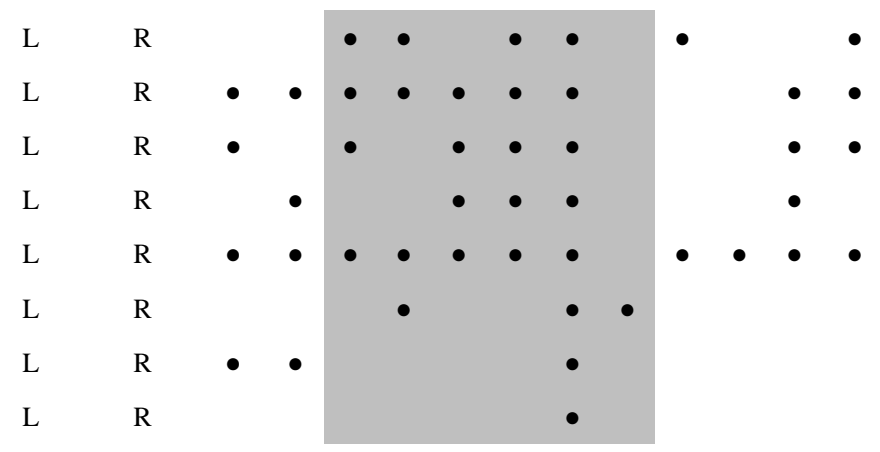

L $\quad \mathrm{R}$

L $\quad \mathrm{R}$

$\begin{array}{lll}\text { L } & \text { R } \\ \text { L } & \text { R } \\ \text { L } & \text { R } \\ \text { L } & \text { R } \\ \text { L } & \text { R }\end{array}$

L R

L $\quad \mathrm{R}$

L R

L $\quad \mathrm{R}$

L $\quad \mathrm{R}$

L VN

L $\quad \mathrm{R}$

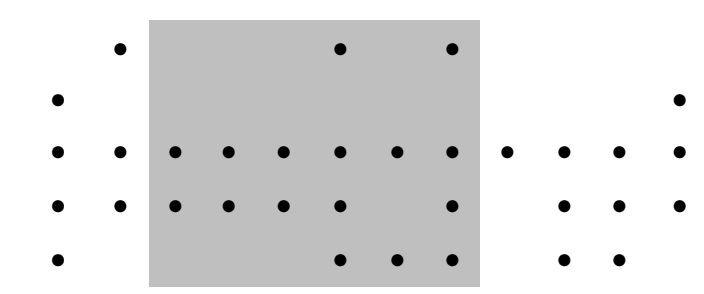

(2)
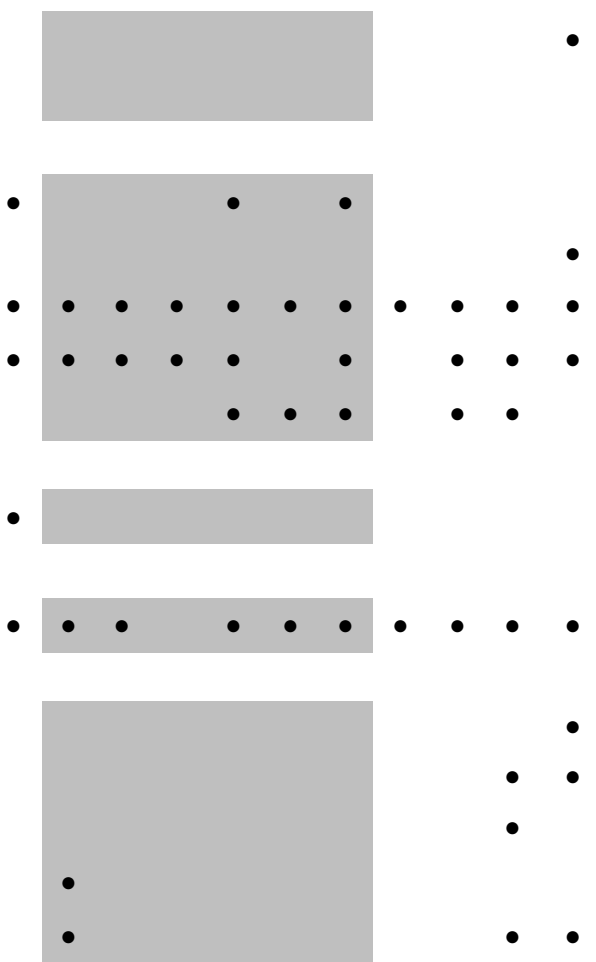

L $\mathrm{R}$

L $\quad$ R 


\section{Continued}

\section{Trochilidae}

Eupetomena macroura (Gmelin, 1788)

Polytmus guainumbi (Pallas, 1764)

Amazilia fimbriata (Gmelin, 1788)

\section{Alcedinidae}

Megaceryle torquata (Linnaeus, 1766)

Chloroceryle amazona (Latham, 1790)

\section{Picidae}

Picumnus cirratus Temminck, 1825

Melanerpes candidus (Otto, 1796)

Colaptes campestris (Vieillot, 1818)

\section{Furnariidae}

Furnarius figulus (Lichtenstein, 1823)

Furnarius rufus (Gmelin, 1788)

Phleocryptes melanops (Vieillot, 1817)

Certhiaxis cinnamomeus (Gmelin, 1788)

Phacellodomus rufifrons (Wied, 1821)

\section{Rhynchocyclidae}

Tolmomyias flaviventris (Wied, 1831)

Todirostrum cinereum (Linnaeus, 1766)

Hemitriccus nidipendulus (Wied, 1831)

\section{Tyrannidae}

Euscarthmus meloryphus Wied, 1831

Camptostoma obsoletum (Temm., 1824)

Elaenia flavogaster (Thunberg, 1822)

Elaenia spectabilis Pelzeln, 1868

Pseudocolopteryx sclateri (Oust., 1892)

Serpophaga subcristata (Vieillot, 1817)

Myiarchus ferox (Gmelin, 1789)

Pitangus sulphuratus (Linnaeus, 1766)

Machetornis rixosa (Vieillot, 1819)

Megarynchus pitangua (Linnaeus, 1766)

Myiozetetes similis (Spix, 1825)

Tyrannus melancholicus Vieillot, 1819

Tyrannus savana Vieillot, 1808

Fluvicola albiventer (Spix, 1825)

Fluvicola nengeta (Linnaeus, 1766)

Arundinicola leucocephala (L., 1764)

Satrapa icterophrys (Vieillot, 1818)

Xolmis velatus (Lichtenstein, 1823)

$\begin{array}{lll}\mathrm{L} & \mathrm{R} & \bullet \\ \mathrm{L} & \mathrm{R} & \\ \mathrm{L} & \mathrm{R} & \bullet\end{array}$

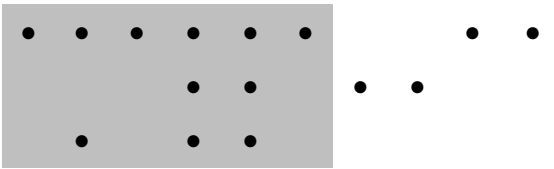

W R

W R
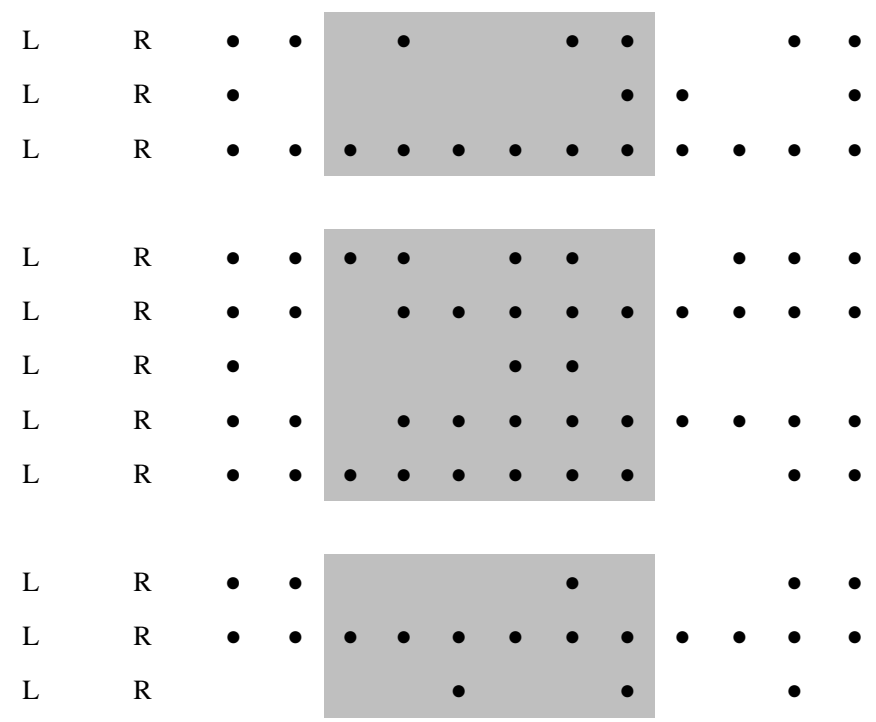

L

L R

L R

L R

L R

L R

L R

L R

L R

L R

L R

L R

L R

L $\mathrm{R}$

L R

L R

L R

L R

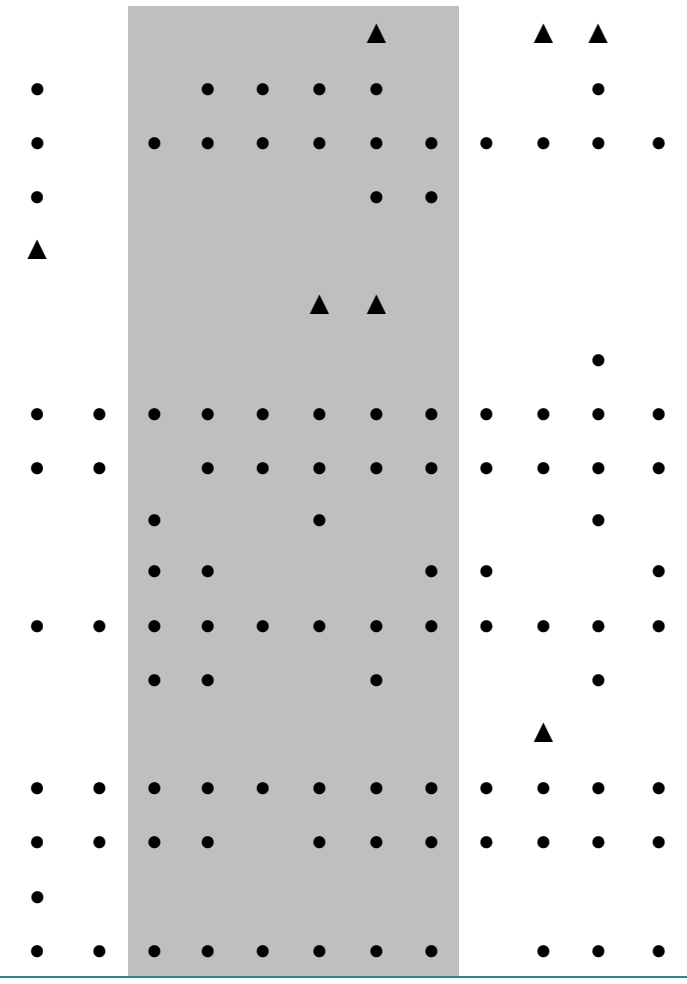




\section{Continued}

\section{Vireonidae}

Vireo olivaceus (Linnaeus, 1766)

Hylophilus thoracicus Temminck, 1822

\section{Hirundinidae}

Pygochelidon cyanoleuca (Vieillot, 1817)

Progne tapera (Vieillot, 1817)

Progne chalybea (Gmelin, 1789)

Tachycineta albiventer (Boddaert, 1783)

Tachycineta leucorrhoa (Vieillot, 1817)

Tachycineta leucopyga (Meyen ,1834)

Riparia riparia (Linnaeus, 1758)

Hirundo rustica Linnaeus, 1758

Petrochelidon pyrrhonota (Vieillot, 1817)

\section{Troglodytidae}

Troglodytes musculus Naumann, 1823

\section{Donacobidae}

Donacobius atricapilla (Linnaeus, 1766)

\section{Turdidae}

Turdus rufiventris Vieillot, 1818

Turdus amaurochalinus Cabanis, 1850

\section{Mimidae}

Mimus gilvus (Vieillot, 1807) ${ }^{\mathrm{En}}$

Mimus saturninus (Lichtenstein, 1823)

\section{Motacillidae}

Anthus lutescens Pucheran, 1855

\section{Coerebidae}

Coereba flaveola (Linnaeus, 1758)

\section{Thraupidae} Ramphocelus bresilius (Linnaeus, 1766)

Lanio pileatus (Wied, 1821)

Tangara sayaca (Linnaeus, 1766)

Tangara palmarum (Wied, 1823)

Tangara cayana (Linnaeus, 1766)

Paroaria dominicana (Linnaeus, 1758)

Dacnis cayana (Linnaeus, 1766)

Cyanerpes cyaneus (Linnaeus, 1766)

Conirostrum speciosum (Temminck, 1824)

\section{Emberizidae}

Thlypopsis sordida (d’Orb. \& Lafr., 1837)

Zonotrichia capensis (Statius Muller, 1776)

L R

L $\quad \mathrm{R}$

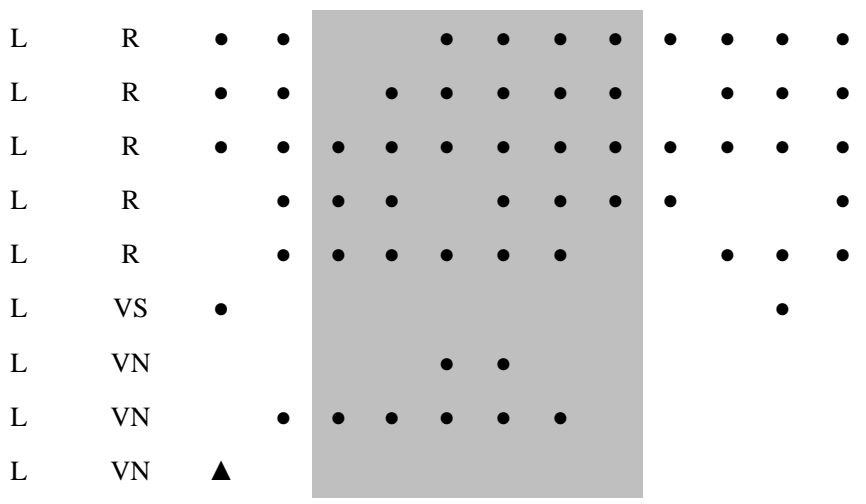

L $\quad \mathrm{R}$

L $\quad \mathrm{R}$

L $\quad \mathrm{R}$

L R

$\mathrm{L} \quad \mathrm{R}$

L $\quad \mathrm{R}$

L R

L $\quad \mathrm{R}$
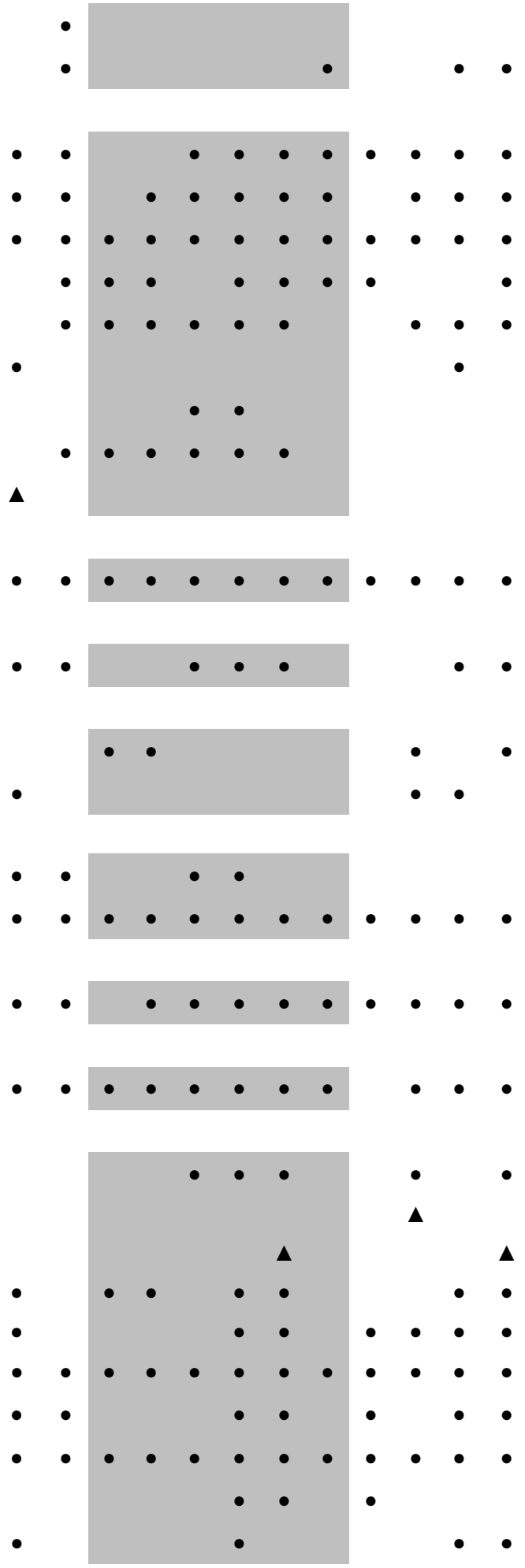

L $\quad \mathrm{R}$

$\mathrm{L} \quad \mathrm{R}$

L $\quad \mathrm{R}$

L $\quad \mathrm{R}$

L $\quad \mathrm{R}$

L $\quad \mathrm{R}$

L $\quad \mathrm{R}$

L $\quad R$

L $\quad \mathrm{R}$

L $\quad \mathrm{R}$

L $\quad$ R

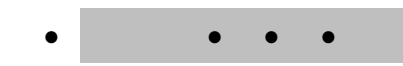




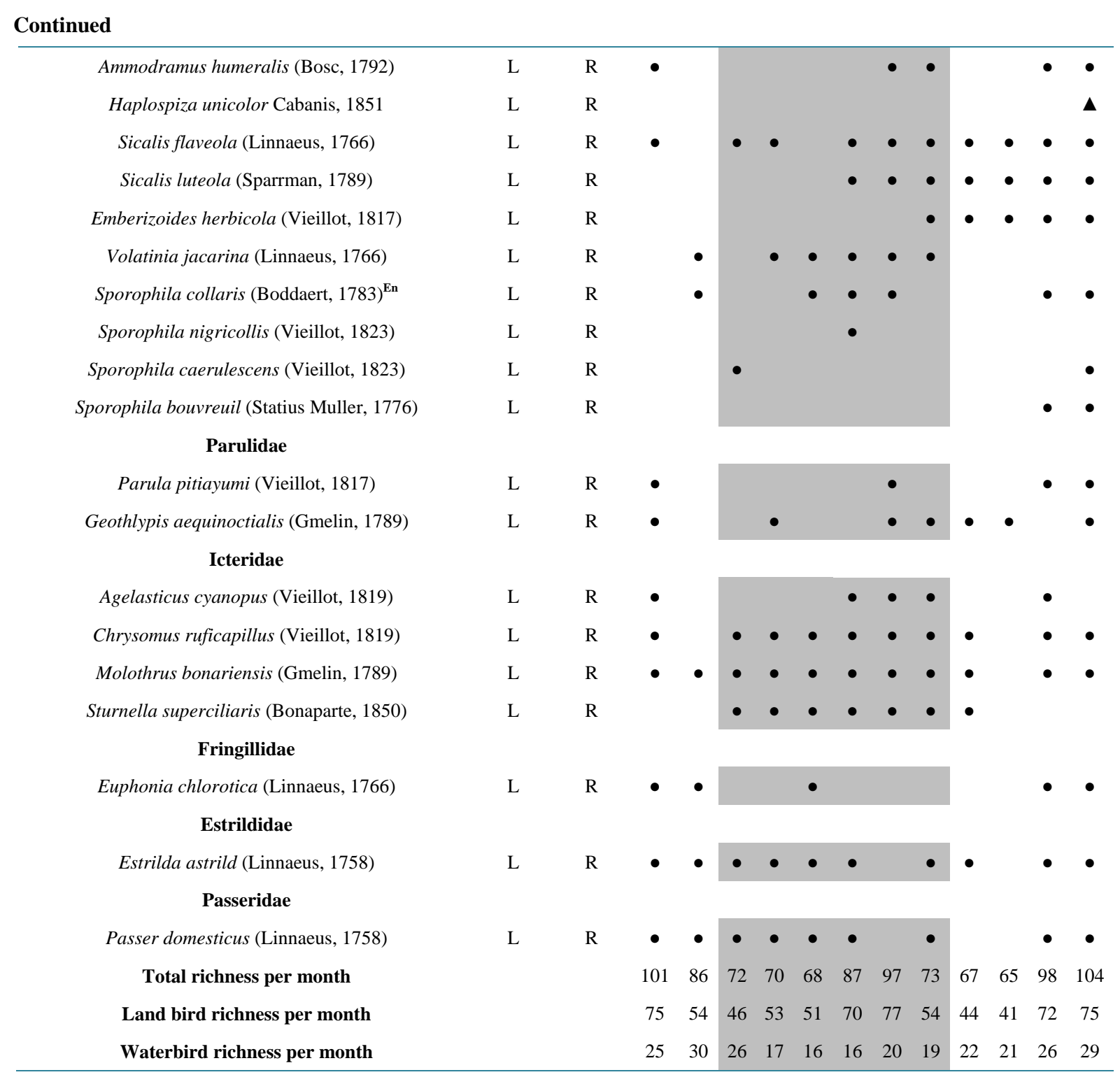

